policies, and informing current and future security leaders. Research areas include: US national security and defence policy; regional security challenges; national security; US military forces and operations; terrorism, irregular warfare and crime; weapons of mass destruction and nuclear proliferation.

\author{
Address: 1152 15th St., NW, Suite 950, Washington, D.C., \\ 20005, USA. \\ Website: http://www.cnas.org \\ President: Richard Fontaine.
}

\section{Center for American Progress}

Founded 2003. Organization dedicated to improving the lives of Americans through progressive ideas and action. Research issues: domestic; economy; national security; energy and environment; media and progressive values.

Address: 1333 H St., NW, 10th Floor, Washington, D.C., 20005, USA.

Website: http://www.americanprogress.org

President: Neera Tanden.

\section{Center for Strategic and International Studies}

Founded in 1962 during the Cold War to find ways for the USA to sustain its prominence and prosperity as a force for good in the world. Bipartisan, non-profit organization that conducts research and analysis and develops policy initiatives that look into the future and anticipate change. Research focuses on defence and security, energy and climate change, global health, global trends and forecasting, governance, human rights, technology, and trade and economics.

Address: 1616 Rhode Island Ave., NW, Washington, D.C., 20036, USA.

Website: http://www.csis.org

President: John J. Hamre.

\section{Centre for Economic Policy Research}

Founded 1983. Non-profit, educational research network that promotes independent, objective analysis and public discussion of open economies and the relations among them. Programmes: development economics; financial economics; industrial organization; international macroeconomics; international trade and regional economics; labour economics; public policy.

Address: 33 Great Sutton St., London EC1V 0DX, UK.

Website: http://www.cepr.org

Director: Richard Baldwin.

\section{Centre for European Policy Studies}

Founded 1983. Independent institute specializing in European affairs. Research programmes: economic and social welfare policies; energy, climate change and sustainable development; EU neighbourhood, foreign and security policy; financial markets and institutions; justice and home affairs; politics and European institutions; regulatory policy; trade developments and agricultural policy.

Address: 1 Place du Congrès, B-1000 Brussels, Belgium.

Website: http://www.ceps.eu

Director: Daniel Gros.

\section{Centro Brasileiro de Relações Internacionais}

Founded 1998. Independent, non-profit research institution and a leading forum for international relations and foreign policy discussions in Brazil. It is widely recognized for the study and debate of crucial themes of Brazilian foreign policy. Research issues: Brazil in the World; Brazil in the Americas; Global Issues in the International Agenda.

Address: Rua da Candelária 9, Grupo 201, 20091-904

Rio de Janeiro, Brazil.

Website (Portuguese only): http://www.cebri.org

Executive Director: Julia Dias Leite.

\section{Chatham House \\ (Royal Institute of International Affairs)}

Founded 1920. Leading independent think tank whose research centres on three areas: energy, environment and resource governance; international economics; regional and security studies. Established the 'Chatham House Rule' that aids free and open debate by allowing for anonymity of speakers at meetings. Sister organization of Council on Foreign Relations in New York.

Address: 10 St James' Square, London SW1Y 4LE, UK.

Website: http://www.chathamhouse.org

Director: Dr Robin Niblett.

\section{China Institute of International Studies (CIIS)}

Founded 1956. The think tank of China's ministry of foreign affairs focuses on global politics and economics and the decisionmaking process of the central government. Research at the Institute centres on medium and long-term policy issues of strategic importance, specifically those concerning international politics and the world economy.

Address: 3 Toutiao, Taijichang, Beijing 100005, China.

Website: http://www.ciis.org.cn

President: Su Ge.

\section{China Institutes of Contemporary International Relations}

Founded 1965. Influential research institution of international studies devoted to a wide range of political, economic, diplomatic, military and social issues spanning all continents as well as issues related to Hong Kong, Macao and Taiwan. A key research area is the United States and the Sino-US relationship.

Address: A-2 Wanshousi, Haidian District, Beijing 100081,

China.

Website (Chinese only): http://www.cicir.ac.cn

President: Ji Zhiye.

\section{Chinese Academy of Social Sciences}

Founded 1977. China's highest academic research organization in the fields of philosophy and social sciences. Comprises 32 research institutes, three research centres and a graduate school. Research covers 120 key areas.

Address: 5 Jianguomennei Dajie, Beijing 100732, China.

Website: http://cass.cssn.cn

President: Wang Weiguang.

\section{Council on Foreign Relations}

Founded 1921. Independent think tank that seeks to foster better understanding of the world and the foreign policy choices facing the USA and other countries. Research by the David Rockefeller Studies Program centres on major geopolitical areas but also covers global health, international institutions and global 